\title{
HCV co-infection in HIV positive population in British Columbia, Canada
}

\author{
Jane A Buxton*1,2, Amanda Yu1,2, Paul H Kim¹, John J Spinelli2,3, Margot Kuo', Maria Alvarez', Mark Gilbert1,2 and \\ Mel Krajden ${ }^{1}$
}

\begin{abstract}
Background: As HIV and hepatitis C (HCV) share some modes of transmission co-infection is not uncommon. This study used a population-based sample of HIV and HCV tested individuals to determine the prevalence of HIV/HCV coinfection, the sequence of virus diagnoses, and demographic and associated risk factors.

Methods: Positive cases of HIV were linked to the combined laboratory database (of negative and positive HCV antibody results) and HCV reported cases in British Columbia (BC).

Results: Of 4,598 HIV cases with personal identifiers, 3,219 (70\%) were linked to the combined HCV database, 1,700 (53\%) of these were anti-HCV positive. HCV was diagnosed first in $52 \%$ of co-infected cases (median time to HIV identification $31 / 2$ years). HIV and HCV was diagnosed within a two week window in $26 \%$ of cases. Among individuals who were diagnosed with HIV infection at baseline, subsequent diagnoses of HCV infection was independently associated with: i) intravenous drug use (IDU) in males and females, Hazard Ratio (HR) $=6.64$ (95\% Cl: 4.86-9.07) and 9.76 (95\% Cl: 5.76-16.54) respectively; ii) reported Aboriginal ethnicity in females $\mathrm{HR}=2.09$ (95\% Cl: 1.34-3.27) and iii) males not identified as men-who-have-sex-with-men (MSM), HR= 2.99 (95\% Cl: 2.09-4.27).

Identification of HCV first compared to HIV first was independently associated with IDU in males and females OR = 2.83 (95\% Cl: 1.84-4.37) and 2.25 (95\% Cl: 1.15-4.39) respectively, but not Aboriginal ethnicity or MSM. HIV was identified first in $22 \%$, with median time to HCV identification of 15 months;

Conclusion: The ability to link BC public health and laboratory HIV and HCV information provided a unique opportunity to explore demographic and risk factors associated with HIV/HCV co-infection. Over half of persons with HIV infection who were tested for HCV were anti-HCV positive; half of these had HCV diagnosed first with HIV identification a median 3.5 years later. This highlights the importance of public health follow-up and harm reduction measures for people identified with HCV to prevent subsequent HIV infection.
\end{abstract}

\section{Background}

HIV and hepatitis $\mathrm{C}(\mathrm{HCV})$ are major burdens on the health care system in Canada and share some common modes of transmission. $\mathrm{HCV}$ co-infection is estimated to occur in $20 \%$ of Canadians infected with HIV [1] and 50$90 \%$ of HIV-positive persons who use drugs intravenously [2-4]. Compared to HIV mono-infected individuals, HIV/ $\mathrm{HCV}$ co-infected groups are characterized by a higher prevalence of injection drug use, poverty, and psychiatric disorders [5].

\footnotetext{
* Correspondence: jane.buxton@bccdc.ca

1 BC Centre for Disease Control, Vancouver, British Columbia Full list of author information is available at the end of the article
}

Co-infection affects disease progression related to both agents [6-12] and complicates treatment [13-15]. The rate of liver cirrhosis is up to six times higher in HIV coinfected persons than HCV mono-infected [12,16-19]. Effective anti-retroviral therapies have improved the life expectancy of persons with HIV so that persons coinfected with chronic HCV survive to develop HCV cirrhosis.

Clinical management and treatment of co-infected patients is challenging and complex [13-15]. Abnormal hepatic function is one of the most common complications occurring among HIV-infected individuals receiving anti-retroviral therapy [14,20,21]. Consensus guildelines for co-infection state all HIV-infected individ- 
uals should be screened for HCV, and those with coinfection should be considered for anti-HCV treatment, even though response to anti-HCV therapy is lower in coinfected patients $[14,16,20,21]$. As antiretoviral hepatotoxicity may be increased in the presence of $\mathrm{HCV}$ infection, ideally $\mathrm{HCV}$ treatment should be intiated before anti-HIV therapy when HIV infection is stable [22]. However, treating HIV first is clearly indicated when CD4 lymphocyte count is very low ( $<200$ cells/microL) [13].

Although data on HIV/HCV co-infection is available from defined study cohorts such as persons who use intravenous drugs (IDU) and men who have sex with men (MSM) there is little population-based data. All confirmatory HIV testing in British Columbia (BC) and 95\% of anti-HCV testing is performed at the Provincial Public Health Reference laboratory. First positive HIV tests in $\mathrm{BC}$ are reported to the STI/HIV Prevention and Control Division at BC Centre for Disease Control (BCCDC). Since 1995 more than 6,000 cases of HIV have been reported, and risk factor information at the time of HIV identification collected. All newly identified cases of $\mathrm{HCV}$, who are resident in $\mathrm{BC}$ and not previously reported elsewhere in Canada, are reported by the five regional public health authorities (Figure 1) into the BC integrated Public Health Information System (iPHIS), which is coordinated at BCCDC. Approximately 65,000 antibody reactive cases of HCV have been reported into iPHIS since 1992.

The aim of this study was to link positive cases of HIV with both anti-HCV positive cases and anti-HCV negative testers identified in the $\mathrm{BC}$ surveillance and laboratory systems in order to determine prevalence of HIV/ $\mathrm{HCV}$ co-infection. The sequence of virus diagnosis, demographic characteristics and associated risk factors at the time of HIV infection were determined. This linkage enables the estimation of the current and projected burden of disease in order to guide prevention, testing and care programs, and appropriate resource allocation.

\section{Methods}

\section{Data sources}

The STI/HIV Prevention and Control database (HIV dataset) which contains all anti-HIV positive individuals (confirmed by HIV Western Blot) was linked to the combined BCCDC laboratory $\mathrm{HCV}$ testing database and reported HCV cases in iPHIS (HCV dataset). The timeframe of the data linkage was from January $1^{\text {st }} 1995$ to December $31^{\text {st }} 2008$.

$\mathrm{HCV}$ antibody testing was performed using second- or third-generation enzyme-linked immunosorbent assays (EIA) including Organon Teknika (UBI) v2.0, v2.1, v4.0 (Organon Teknika, Durham, North Carolina) and Abbott AxSYM HCV 3.0 (Abbott Diagnostics, Chicago, Illinois). Specimens reactive for anti-HCV were retested by the second or third generation Recombinant Immunoblot Assay (Chiron, Emeryville, California) until July 1999 to confirm EIA specificity. Between April 1997 and February 2004, Abbott AxSYM HCV 3.0 anti-HCV reactive specimens were re-tested by either Organon Teknika (UBI) v4.0 or Ortho EcI (Ortho, Canada). Thereafter, anti-HCV screening was performed on the ADVIA Centaur (initially Bayer, Canada, now Siemens, Canada) and anti-HCV reactive samples re-tested on the Abbott Architect (Abbott, Canada). Only specimens reactive by both manufacturers' tests were considered to be anti$\mathrm{HCV}$ reactive. As $\mathrm{HCV}$ RNA test results (qualitative COBAS AMPLICOR HCV Test v2.0 (Roche Diagnostic Systems, Mississauga, Canada) were only available on a subset of $\mathrm{HCV}$ antibody positive cases these data were not included in our analysis. Data elements include first and last name, personal health number, date of birth, sex, location (health region of residence of the subject at the time of HIV virus identification), ethnicity (self- or clinician-reported), date each virus was identified, and exposure category(ies) at the time HIV infection was identified.

\section{Data management and confidentiality}

The HIV and HCV datasets were linked on personal identifiers; after which nominal information was permanently deleted and a unique study code was allocated. To maintain confidentiality the linkage process was performed by computer programmed algorithms without displaying personal identifiers. All datasets used in the linkage process with retained identifiers were permanently deleted leaving only the final, linked, anonymized dataset to be used for the statistical analyses. Data manipulation and analyses were performed using SAS version 9.1.3 for Windows (SAS Institute, Cary, NC).

All first positive HIV cases, identified from January $1^{\text {st }}$ 1995 to December $31^{\text {st }} 2008$ with personal identifiers, were linked with the combined HCV dataset. Those with $\mathrm{HCV}$ and HIV first identified within 2 weeks were considered simultaneous identification. Ethical approval was received from the UBC Clinical Research Ethics Board.

\section{Statistical analysis}

Cases aged $<15$ years and non-BC residents were excluded. Univariate logistic regression was used to compare linked and unlinked subjects. Univariate and multivariate Cox proportional hazard regression were used to estimate the hazard ratios (HR) and 95\% confidence intervals of $\mathrm{HIV} / \mathrm{HCV}$ co-infection among individuals with HIV mono-infection at baseline. Univariate and multivariate logistic regression were used to assess the association between the sequence of virus identification and explanatory variables among co-infected individuals; odds ratios (OR) and 95\% Wald confidence intervals were 


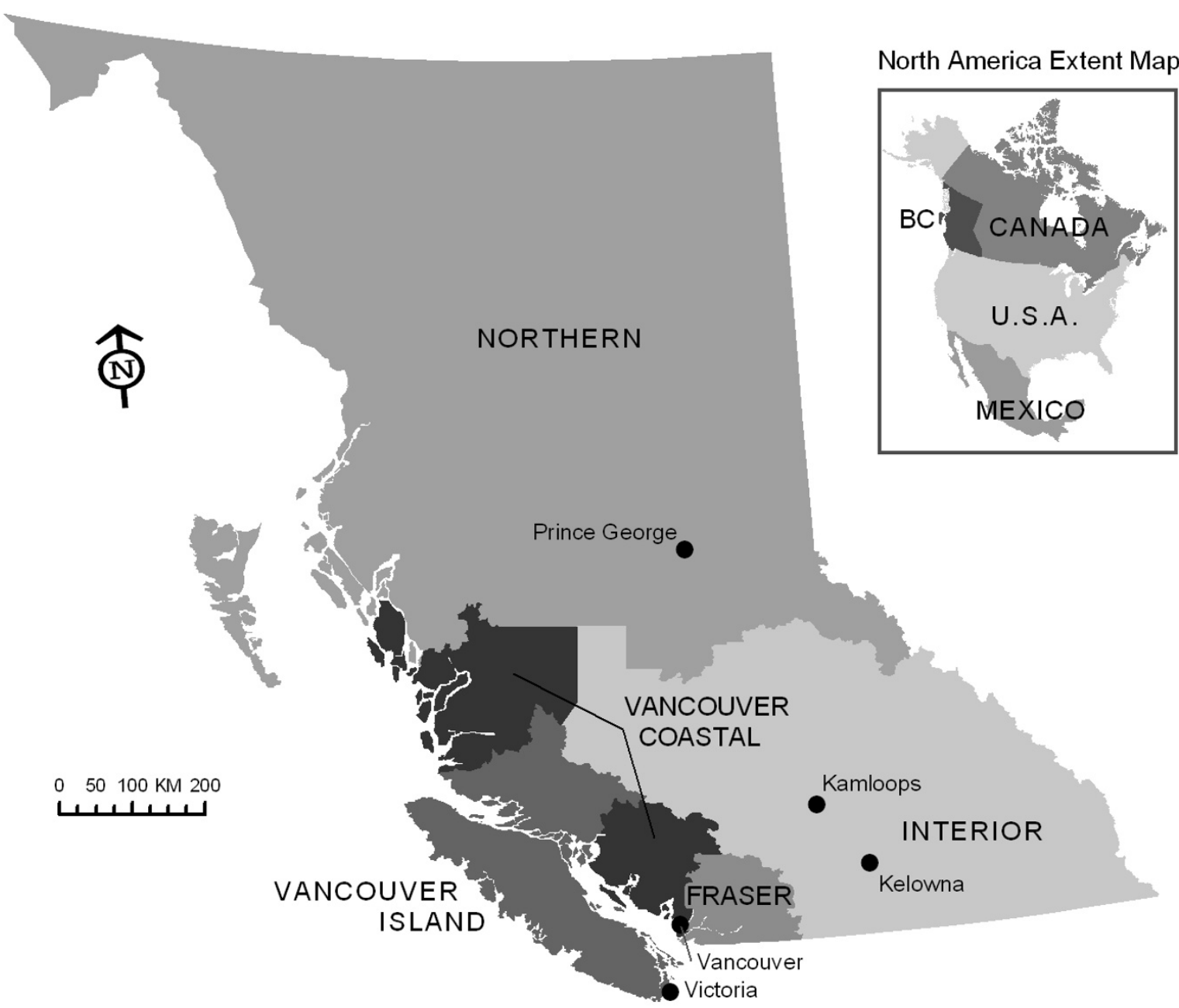

Figure 1 British Columbia map of health authorities

estimated. Multivariate regression analyses were conducted separately by sex as predictive factors were different for males and females, covariates included age, ethnicity, health authority of residence at HIV infection and IDU for both sexes; MSM was included for males.

\section{Results}

A total of 6,288 HIV cases were eligible for analysis; 4,598 (73\%) had personal identifiers and therefore were potentially linkable to the combined HCV dataset. The HCV dataset comprised test results from 914,442 individuals, of whom 69,339 (7.6\%) were anti-HCV antibody positive. In total, 3,219 (70\%) HIV cases were linked to the HCV dataset (Figure 2). The HIV positive population that was linked to the HCV dataset were younger than those not linked; mean age 37.9 vs. $39.3(\mathrm{t}=4.00, \mathrm{p}<0.0001)$. In univariate analysis those linked were more likely to be female (O.R. 2.01, 95\% CI 1.70-2.38), Aboriginal (O.R. $1.96,95 \%$ CI 1.60-2.41), and to not reside in Vancouver Coastal Health Region (O.R. 1.90, 95\% CI 1.67-2.16).

Of the 3,219 persons with HIV that were linked to the HCV dataset, 1,700 (53\%) were co-infected; i.e. at least $27 \%$ of all HIV cases. Within those co- infected, HCV was diagnosed first in $52 \%$ of cases, with a median time to subsequent HIV identification 3 1/2 years; 26\% were diagnosed at about the same time ( \pm 2 weeks); HIV was identified first in $22 \%$, with median time to HCV identification of 15 months (Figure 2).

Among individuals who were HIV mono-infected at baseline, subsequent diagnosis of HCV (compared to persons without a HCV infection diagnosis) using univariate analysis was significantly associated with younger age at HIV identification, reported Aboriginal ethnicity, 


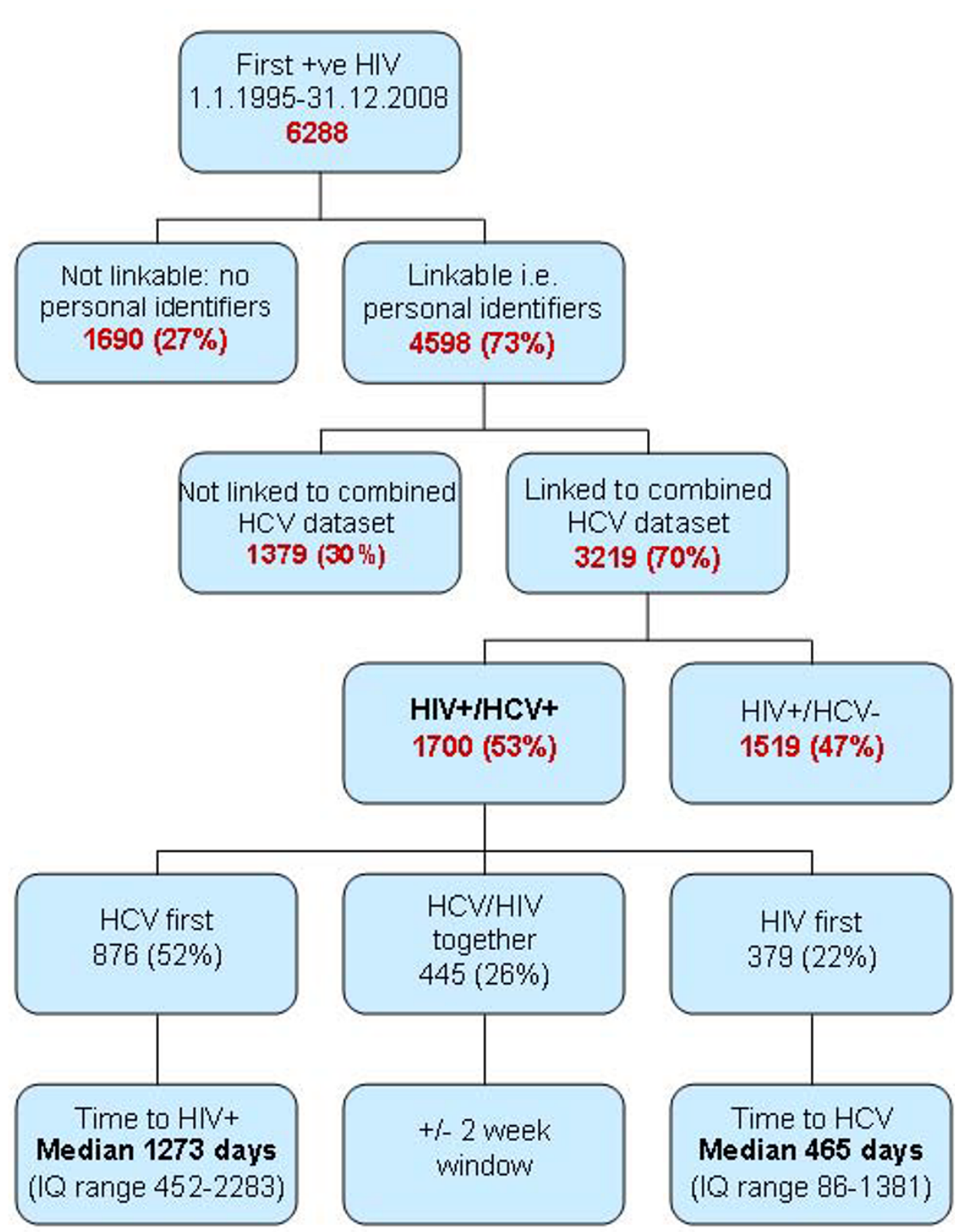

Figure 2 HIV data linked with HCV dataset; January 1, 1995 to December 31, 2008

reported IDU and not being identified as MSM in males (Table 1).

The Cox proportional hazard assumption was tested by including the interactions of predictors and log survival time as time dependent covariates in the model. The results suggested that the proportionality assumption of the model was not violated. In multivariable Cox regression model of individuals who were HIV mono-infected 
Table 1: HIV mono-infected cases at baseline linked to HCV dataset January 1, 1995 to December 31, 2008

\begin{tabular}{|c|c|c|c|c|c|c|c|c|}
\hline \multirow{2}{*}{$\begin{array}{l}\mathbf{N} \\
\mathbf{N}\end{array}$} & \multicolumn{2}{|c|}{$\begin{array}{c}\text { HCV not detected } \\
(\%)\end{array}$} & \multicolumn{2}{|c|}{$\begin{array}{c}\text { HCV co-infected } \\
\text { (\%) }\end{array}$} & \multicolumn{2}{|c|}{$\begin{array}{c}\text { Unadjusted } \\
\text { HR }\end{array}$} & \multicolumn{2}{|c|}{$\begin{array}{l}\text { 95\% Confidence } \\
\text { Limits }\end{array}$} \\
\hline & & & & & & & & \\
\hline Age at HIV & & & & & & & & \\
\hline Mean & & & & & & & & \\
\hline Std & & & & & & & & \\
\hline Range & & & & & & & & \\
\hline \multicolumn{9}{|l|}{ Sex } \\
\hline Male & & & & & & & & \\
\hline Female & & & & & & & & \\
\hline Transgender & & & & & & & & \\
\hline $\begin{array}{l}\text { Unknown/ } \\
\text { missing }\end{array}$ & & & & & & & & \\
\hline \multicolumn{9}{|l|}{ Ethnicity } \\
\hline $\begin{array}{l}\text { Non- } \\
\text { Aboriginal }\end{array}$ & & & & & & & & \\
\hline Aboriginal & & & & & & & & \\
\hline $\begin{array}{l}\text { Unknown/ } \\
\text { missing }\end{array}$ & & & & & & & & \\
\hline \multicolumn{9}{|l|}{$\begin{array}{l}\text { Health } \\
\text { Authority }\end{array}$} \\
\hline $\begin{array}{l}\text { Vancouver } \\
\text { Coastal }\end{array}$ & & & & & & & & \\
\hline Fraser & & & & & & & & \\
\hline Interior & & & & & & & & \\
\hline Northern & & & & & & & & \\
\hline $\begin{array}{l}\text { Vancouver } \\
\text { Island }\end{array}$ & & & & & & & & \\
\hline \multirow[t]{2}{*}{ Missing } & & & & & & & & \\
\hline & Male & Female & Male & Female & Male & Female & Male & Female \\
\hline \multicolumn{9}{|l|}{ MSM } \\
\hline Yes & $\begin{array}{c}796 \\
(64.5)\end{array}$ & - & $\begin{array}{c}47 \\
(17.7)\end{array}$ & - & 1.00 & & & \\
\hline No & $\begin{array}{c}438 \\
(35.5)\end{array}$ & - & $\begin{array}{c}218 \\
(82.3)\end{array}$ & - & 5.40 & & $\begin{array}{l}3.90- \\
7.49\end{array}$ & - \\
\hline \multicolumn{9}{|l|}{ IDU } \\
\hline Yes & $\begin{array}{l}122 \\
(9.9)\end{array}$ & $\begin{array}{c}37 \\
(13.5)\end{array}$ & $\begin{array}{c}169 \\
(63.8)\end{array}$ & $\begin{array}{c}81 \\
(72.3)\end{array}$ & 10.33 & 10.94 & $\begin{array}{l}7.76- \\
13.77\end{array}$ & $\begin{array}{l}6.61- \\
18.10\end{array}$ \\
\hline No & $\begin{array}{l}1112 \\
(90.1)\end{array}$ & $\begin{array}{c}237 \\
(86.5)\end{array}$ & $\begin{array}{c}96 \\
(36.2)\end{array}$ & $\begin{array}{c}31 \\
(27.7)\end{array}$ & 1.00 & 1.00 & & \\
\hline
\end{tabular}


at baseline (Table 2), males aged 45+ at HIV identification were less likely to become co-infected compared to males aged 15-24, (HR 0.55, 95\% CI: 0.31-0.97), but age was not significant for females. Males and females who reported IDU were more likely to become co-infected: HR 6.64, 95\% CI: 4.86-9.07 and HR 9.76, 95\% CI: 5.76-16.54 respectively. Females reporting Aboriginal ethnicity were twice as likely to become co-infected (HR 2.09, 95\% CI: 1.34-3.27); ethnicity was not significant for males. Males not identified as MSM were more likely to become coinfected (HR 2.99, 95\% CI: 2.09-4.27).

Diagnosis of HCV before HIV in univariate analysis of co-infected individuals was significantly associated with older age, female sex, reported IDU and not being identified as MSM in males (Table 3). In the separate multivariate logistic regression models for males and females, $\mathrm{HCV}$ diagnosis before HIV was significantly associated with age and IDU in both sexes (Table 4). The majority of persons co-infected reported IDU as the major risk factor; a small proportion (6.2\%) of co-infected males reported both MSM and IDU and 5.4\% reported MSM only (Table 5).

\section{Discussion}

This study provides important new information from a population-based sample of HIV and HCV tested individuals. We are able to provide a robust estimate of those who have been infected with both $\mathrm{HCV}$ and HIV, the order of virus identification and associated risk factors. Previous studies which assess co-infection have typically been cross-sectional surveys or longitudinal cohorts following persons who inject drugs or are MSM and therefore results are more likely to be population specific or affected by selection bias.

This study uses anti-HCV positivity to define $\mathrm{HCV}$ infection and co-infection. We recognize that approximately $25 \%$ (range $15 \%$ to $45 \%$ ) of infected individuals will clear infection spontaneously [23]. As HCV-RNA testing was available only in a subgroup of anti-HCV positive individuals, we are unable to confirm active $\mathrm{HCV}$ infection in individuals diagnosed with HCV. Therefore our study overestimates the number of individuals who are actually HCV/HIV co-infected.

The HIV/HCV co-infection rate in our HIV seropositive sample is high compared to other studies [1]; over half of persons with HIV who were tested for HCV were found to be HCV positive. In a population sample persons who are at highest risk for $\mathrm{HCV}$ infection such as IDU may be more likely to be tested and therefore overestimate co-infection. IDU was independently associated with $\mathrm{HCV}$ co-infection in both sexes, but reported aboriginal ethnicity was significant in females only. Among a cohort of IDU aged $<30$ years in Vancouver, coinfection at baseline was independently associated with

Table 2: Adjusted hazard ratios (Cox regression) for risk of co-infection

\begin{tabular}{|c|c|c|c|c|}
\hline & \multicolumn{2}{|c|}{ Adjusted HR* } & \multicolumn{2}{|c|}{$\begin{array}{l}\text { 95\% Confidence } \\
\text { Limits }\end{array}$} \\
\hline & $\begin{array}{c}\text { Male } \\
(\mathrm{N}=137)\end{array}$ & $\begin{array}{l}\text { Female } \\
(\mathrm{N}=\mathbf{3 5 4})\end{array}$ & Male & Female \\
\hline \multicolumn{5}{|l|}{ Age group at HIV } \\
\hline $\begin{array}{l}25-34 \text { years vs. } \\
15-24 \text { years }\end{array}$ & 0.77 & 1.19 & $0.47-1.27$ & $0.72-1.97$ \\
\hline $\begin{array}{l}35-44 \text { years vs. } \\
15-24 \text { years }\end{array}$ & 0.78 & 1.55 & $0.48-1.27$ & $0.89-2.70$ \\
\hline $\begin{array}{l}45+\text { years vs. } \\
15-24 \text { years }\end{array}$ & 0.55 & 0.99 & $0.31-0.97$ & $0.39-2.49$ \\
\hline \multicolumn{5}{|c|}{ Health Authority (HA) vs. Vancouver Coastal HA } \\
\hline Fraser HA & 0.81 & 1.06 & $0.58-1.12$ & $0.62-1.81$ \\
\hline Interior HA & 0.89 & 1.41 & $0.48-1.66$ & $0.59-3.39$ \\
\hline Northern HA & 0.73 & 0.51 & $0.32-1.69$ & $0.16-1.68$ \\
\hline $\begin{array}{l}\text { Vancouver Island } \\
\text { HA }\end{array}$ & 1.10 & 2.23 & $0.70-1.71$ & $1.28-3.89$ \\
\hline Aboriginal Yes vs. No & 1.29 & 2.09 & $0.88-1.88$ & 1.34-3.27 \\
\hline IDU Yes vs. No & 6.64 & 9.76 & $4.86-9.07$ & $5.76-16.54$ \\
\hline MSM No vs. Yes & 2.99 & & $2.09-4.27$ & \\
\hline
\end{tabular}

*Separate model for males and females. Models include age at HIV, IDU, aboriginal ethnicity, Health Authority and MSM (for males only) 
Table 3: Order of virus identification for individuals with HIV/HCV co-infection, January $1^{\text {st }} 1995$ - December $31^{\text {st }}, 2008$

\begin{tabular}{|c|c|c|c|c|c|c|c|c|}
\hline & \multicolumn{2}{|c|}{$\begin{array}{l}\text { HIV first } \\
\text { (\%) }\end{array}$} & \multicolumn{2}{|c|}{$\begin{array}{l}\text { HCV first } \\
\text { (\%) }\end{array}$} & \multicolumn{2}{|c|}{$\begin{array}{c}\text { Unadjusted } \\
\text { OR }\end{array}$} & \multicolumn{2}{|c|}{$\begin{array}{c}\text { 95\% Confidence } \\
\text { Limits }\end{array}$} \\
\hline $\mathbf{N}$ & \multicolumn{2}{|c|}{379} & \multicolumn{2}{|c|}{876} & & & & \\
\hline \multicolumn{5}{|l|}{ Age at HIV } & \multicolumn{2}{|c|}{1.05} & \multicolumn{2}{|c|}{$1.04-1.07$} \\
\hline Mean & \multicolumn{2}{|c|}{34.3} & \multicolumn{2}{|c|}{38.6} & & & & \\
\hline Std & \multicolumn{2}{|c|}{9.05} & \multicolumn{2}{|c|}{9.31} & & & & \\
\hline Range & \multicolumn{2}{|c|}{$15-61$} & \multicolumn{2}{|c|}{$18-75$} & & & & \\
\hline \multicolumn{9}{|l|}{ Sex } \\
\hline Male & \multicolumn{2}{|c|}{265 (69.9) } & \multicolumn{2}{|c|}{$559(63.8)$} & \multicolumn{2}{|c|}{1.00} & & \\
\hline Female & \multicolumn{2}{|c|}{$112(29.6)$} & \multicolumn{2}{|c|}{$313(35.7)$} & \multicolumn{2}{|c|}{1.33} & \multicolumn{2}{|c|}{$1.02-1.72$} \\
\hline Transgender & \multicolumn{2}{|c|}{$1(0.3)$} & \multicolumn{2}{|c|}{$3(0.3)$} & & & & \\
\hline $\begin{array}{l}\text { Unknown/ } \\
\text { missing }\end{array}$ & \multicolumn{2}{|c|}{$1(0.3)$} & \multicolumn{2}{|c|}{$1(0.1)$} & & & & \\
\hline \multicolumn{9}{|l|}{ Ethnicity } \\
\hline Non-Aboriginal & \multicolumn{2}{|c|}{$234(61.7)$} & \multicolumn{2}{|c|}{$570(65.1)$} & & & & \\
\hline Aboriginal & & & & & & & & \\
\hline $\begin{array}{l}\text { Unknown/ } \\
\text { missing }\end{array}$ & & & & & & & & \\
\hline $\begin{array}{l}\text { Health } \\
\text { Authority }\end{array}$ & & & & & & & & \\
\hline $\begin{array}{l}\text { Vancouver } \\
\text { Coastal }\end{array}$ & & & & & & & & \\
\hline Fraser & & & & & & & & \\
\hline Interior & & & & & & & & \\
\hline Northern & & & & & & & & \\
\hline $\begin{array}{l}\text { Vancouver } \\
\text { Island }\end{array}$ & & & & & & & & \\
\hline Missing & & & & & & & & \\
\hline & Male & Female & Male & Female & Male & Female & Male & Female \\
\hline MSM & & & & & & & & \\
\hline Yes & $\begin{array}{c}47 \\
(17.7)\end{array}$ & - & $\begin{array}{l}55 \\
(9.8)\end{array}$ & - & 1.00 & & & \\
\hline No & $\begin{array}{c}218 \\
(82.3)\end{array}$ & - & $\begin{array}{c}504 \\
(90.2)\end{array}$ & - & 1.98 & & $\begin{array}{l}1.30- \\
3.01\end{array}$ & - \\
\hline IDU & & & & & & & & \\
\hline Yes & $\begin{array}{c}169 \\
(63.8)\end{array}$ & $\begin{array}{c}81 \\
(72.3)\end{array}$ & $\begin{array}{c}474 \\
(84.8)\end{array}$ & $\begin{array}{c}266 \\
(85.0)\end{array}$ & 3.17 & 2.17 & $\begin{array}{r}2.26- \\
4.46\end{array}$ & $\begin{array}{l}1.28- \\
3.62\end{array}$ \\
\hline No & $\begin{array}{c}96 \\
(36.2)\end{array}$ & $\begin{array}{c}31 \\
(27.7)\end{array}$ & $\begin{array}{c}85 \\
(15.2)\end{array}$ & $\begin{array}{c}47 \\
(15.0)\end{array}$ & 1.00 & 1.00 & & \\
\hline
\end{tabular}


being female, aboriginal ethnicity, involvement in sex trade, older age, greater number of years injecting [4]. Our study population is based on persons who are seropositive for HIV rather than IDU, therefore the results are not directly comparable.

Our study sample does not represent systematic sampling of the population, but is based on all laboratory confirmed HIV infected cases during the study period that were then linked to individuals who had undergone $\mathrm{HCV}$ serologic testing. The sample is therefore biased to those who are offered and undergo testing. Although there is an effort to make testing acceptable and available in clinics and through outreach throughout $\mathrm{BC}$, there may be geographic differences.

To reduce the bias for order of detection, 1995 was chosen as the start date, excluding only $11 \mathrm{HIV}$ cases. HCV has been reportable and testing routinely available since 1992; thus 32,428 individuals prior to 1992 were excluded. However, these would be included if HCV testing occurred at a later date. In addition, 80 positive HIV cases were excluded as aged $<15$ years or non-BC residence.

Between January 1995 to April 1997 anti-HCV testing involved screening with the slightly less sensitive second generation anti-HCV test followed by immunoblot confirmation. Since April 1997 to the end of the study period all testing involved screening with the more sensitive $3^{\text {rd }}$ generation anti-HCV assay and confirmation by a second manufacturer's enzyme immunoassay. Only specimens reactive by both manufacturers' tests were considered to be anti-HCV reactive. Therefore it is unlikely that changes in anti-HCV serological testing over the course of the study impacted HCV diagnostic accuracy.

Our results may have been affected by changes in data quality over time. HIV became a reportable infection in $\mathrm{BC}$ in 2003; at this time enhanced regional public health follow-up of individuals having a new positive HIV test was established resulting in improved ascertainment of ethnicity and exposure categories. The quality of identifier data used for data linkage has also changed over time, and is most complete after 2003. Therefore co-infection of HIV cases identified prior to 2003 may be underreported, or bias introduced in subgroup analyses.

The use of partial identifiers, pseudonyms, or nonnominal testing (a testing option introduced in 2003 for HIV) also affects our ability to link data accurately. In studies which require data linkage, some vulnerable and high risk populations are more likely to be excluded due to lack of personal identifiers or difficulty in obtaining risk factor information. Therefore our study may underestimate the number of HIV cases who are $\mathrm{HCV}$ coinfected.

The HIV positive population that had not been tested for HCV differed by age, sex and ethnicity; therefore, our

Table 4: Adjusted ORs (multivariate logistic regression) of HCV first vs. HIV first

\begin{tabular}{|c|c|c|c|c|}
\hline & \multicolumn{2}{|c|}{ Adjusted OR* } & \multicolumn{2}{|c|}{$\begin{array}{l}\text { 95\% Confidence } \\
\text { Limits }\end{array}$} \\
\hline & $\begin{array}{c}\text { Male } \\
(\mathrm{N}=726)\end{array}$ & $\begin{array}{l}\text { Female } \\
(\mathrm{N}=392)\end{array}$ & Male & Female \\
\hline \multicolumn{5}{|l|}{ Age group at HIV } \\
\hline $25-34$ years vs. $15-24$ years & 1.79 & 2.20 & $0.85-3.77$ & 1.15-4.19 \\
\hline $35-44$ years vs. $15-24$ years & 3.22 & 3.73 & $1.56-6.66$ & 1.87-7.42 \\
\hline $45+$ years vs. $15-24$ years & 7.11 & 8.15 & 3.24-15.59 & 2.88-23.09 \\
\hline \multicolumn{5}{|c|}{ Health Authority (HA) vs. Vancouver Coastal HA } \\
\hline Fraser HA & 1.16 & 1.02 & $0.76--1.77$ & $0.54-1.90$ \\
\hline Interior HA & 2.12 & 1.61 & $1.00-4.49$ & $0.57-4.54$ \\
\hline Northern HA & 2.57 & 5.83 & $0.99-6.72$ & $1.64-20.78$ \\
\hline Vancouver Island HA & 2.67 & 1.18 & $1.57-4.54$ & $0.61-2.28$ \\
\hline Aboriginal Yes vs. No & 1.35 & 1.27 & $0.85-2.15$ & $0.76-2.12$ \\
\hline IDU Yes vs. No & 2.83 & 2.25 & $1.84-4.37$ & $1.15-4.39$ \\
\hline MSM No vs. Yes & 1.48 & & $0.90-2.44$ & \\
\hline
\end{tabular}

*Separate model for males and females. Models include age at HIV, IDU, aboriginal ethnicity, Health Authority and MSM (for males only) 
Table 5: Major risk factor categories HIV/HCV co-infection, BC January 1, 1995- December $31^{\text {st, }} 2008$

\begin{tabular}{lcccc}
\hline MALES & $\begin{array}{c}\text { HCV first (\%) } \\
\mathbf{n = 5 5 9}\end{array}$ & $\begin{array}{c}\text { HIV/HCV Same (\%) } \\
\mathbf{n = 3 2 5}\end{array}$ & $\begin{array}{c}\text { HIV first (\%) } \\
\mathbf{n = 2 6 5}\end{array}$ & $\begin{array}{c}\text { All } \\
\mathbf{n}=\mathbf{1 , 1 4 9}\end{array}$ \\
\hline IDU & $436(78.0)$ & $247(76.0)$ & $154(58.1)$ & $837(72.8)$ \\
MSM & $17(3.0)$ & $13(4.0)$ & $32(12.1)$ & $62(5.4)$ \\
MSM/IDU & $38(6.8)$ & $18(5.5)$ & $15(5.7)$ & $71(6.2)$ \\
Heterosexual Contact & $35(6.3)$ & $26(8.0)$ & $33(12.1)$ & $94(8.2)$ \\
Nilidentified/ & $28(5.0)$ & $18(5.5)$ & $28(10.6)$ & $74(6.4)$ \\
Unknown & & & $3(1.1)$ & $11(1.0)$
\end{tabular}

FEMALES

\begin{tabular}{|c|c|c|c|c|}
\hline & $\begin{array}{c}\text { HCV first (\%) } \\
n=313\end{array}$ & $\begin{array}{l}\text { HIV/HCV Same (\%) } \\
n=120\end{array}$ & $\begin{array}{l}\text { HIV first (\%) } \\
n=112\end{array}$ & $\begin{array}{c}\text { All } \\
n=545\end{array}$ \\
\hline IDU & $266(85.0)$ & $100(83.3)$ & $81(72.3)$ & $447(82.0)$ \\
\hline Heterosexual Contact & $32(10.2)$ & $14(11.7)$ & $22(19.6)$ & $68(12.5)$ \\
\hline $\begin{array}{l}\text { Nil identified/ } \\
\text { Unknown }\end{array}$ & $13(4.2)$ & $5(4.2)$ & $9(8.0)$ & $27(5.0)$ \\
\hline Other & $2(0.6)$ & $1(0.8)$ & $0(0.0)$ & $3(0.6)$ \\
\hline
\end{tabular}

study results cannot be generalized beyond the linked population. As IDU is a well known transmission route for $\mathrm{HCV}$, persons who use intravenous drugs may be more likely to be offered and accept HCV testing. Thus we may have overestimated the odds of IDU in co-infection, but the strength of the association is clear.

Our study population uses an HIV dataset to drive the linkage therefore the major exposure categories were determined according to HIV risk rather than HCV risk. Although the risk factors are similar, they may change over time and differ at the time of HCV co-infection diagnosis from those identified at the time of HIV diagnosis. Ascertainment of accurate exposure categories such as IDU and MSM may not be elicited during follow-up due to social desirability bias.

Our study reflects the initial diagnosis of HIV and $\mathrm{HCV}$; however it cannot determine when the infection occurred nor confirm the order of infection. Over $80 \%$ of persons acutely infected with $\mathrm{HCV}$ are asymptomatic and may have undiagnosed HCV infection for decades [24]. The order of virus detection will also be affected by availability and patterns of testing as well as the patient's willingness to be tested for HCV and/or HIV.

If testing for both viruses occured within 2 weeks we considered this to be simultaneous identification. Patients may have been tested for HIV and HCV due to reported risk factors, or the testing of second virus may immediately follow identification of the first. Some patients maybe diagnosed with co-infection as part of a diagnostic work up for mild or moderate disease, or when they present in the emergency room with opportunistic infections [25].

Although the predominant risk factor for HCV infection reported in HIV seropositive men is IDU [26,27], acquisition of HCV in HIV seropositive MSM without a history of IDU is increasingly reported [28]. In this group, HCV seroconversion has been associated with other sexually transmitted infections such as syphilis or lymphogranuloma venereum and/or sexual practices causing mucosal damage such as fisting [28-30]. We found 5.4\% of co-infected males reported MSM and no history of IDU. This is likely an underestimate due to lack of HCV testing in this group but suggests that sexual transmission of $\mathrm{HCV}$ is occurring in this population. MSM who are HIV infected should be informed that they may be at risk for $\mathrm{HCV}$ even if they do not use intravenous drugs and offered testing, especially if considering HIV treatment [13-15].

HCV was identified first in about half of those who were co-infected, with a median time to HIV detection of about $31 / 2$ years. This highlights the need for effective public health follow-up when $\mathrm{HCV}$ is identified. $\mathrm{HCV}$ is more easily transmitted percutaneously and has a higher prevalence in IDU than HIV. Miller et al studied co-infec- 
tion in a cohort of young IDU and found accessing methadone maintenance therapy in the previous 6 months was protective from seroconversion of the second infection [4]. Identification of $\mathrm{HCV}$ provides an opportunity for public health interventions including testing for other blood borne pathogens such as HIV, and offering appropriate immunizations and harm reduction measures. Engagement through harm reduction such as providing clean needles and other drug use paraphernalia and methadone maintenance can decrease the risk of subsequent HIV infection [31].

\section{Conclusion}

The high prevalence of co-infection supports the need for HCV screening in HIV positive populations. It is important to ensure HIV and HCV testing is accessible and offered in gender and culturally appropriate manner. The ability to link BC public health and laboratory HIV and $\mathrm{HCV}$ information provided a unique opportunity to explore demographic and risk factors associated with $\mathrm{HIV} / \mathrm{HCV}$ co-infection in a large population-based sample. Over half of persons with HIV infection who were tested for $\mathrm{HCV}$ were shown to be anti-HCV positive, and half of these had HCV identified first with HIV identification a median 3.5 years later. This study highlights the importance of public health follow-up and harm reduction measures for people identified with $\mathrm{HCV}$ as a means to prevent subsequent HIV infection.

\section{Competing interests}

The authors declare that they have no competing interests.

\begin{abstract}
Authors' contributions
$J A B$ participated in the design and coordination of the study and drafted the manusript. AY and PHK extracted, manipulated, and prepared the data. JJS provided statistical advice and reviewed the analysis of the data. MaK, MA, and MG contributed with the interpretation of the data. MeK took part in the planning of the study and oversaw the data. All authors read and approved the final manuscript.
\end{abstract}

\section{Acknowledgements}

The authors wish to acknowledge the contributions of Claus Sorensen for his assistance with the data and Andrew Tu for his assistance in the preparation of the manuscript.

\section{Author Details}

${ }^{1} \mathrm{BC}$ Centre for Disease Control, Vancouver, British Columbia, ${ }^{2}$ School of Population and Public Health, University of British Columbia, Vancouver, British Columbia and ${ }^{3}$ BC Cancer Agency, Vancouver, British Columbia

Received: 24 October 2009 Accepted: 29 April 2010

Published: 29 April 2010

\section{References}

1. Sherman M, Shafran S, Burak K, Doucette K, Wong W, Girgrah N, Yoshida E, Renner E, Wong P, Deschenes M: Management of chronic hepatitis C: consensus guidelines. Can J Gastroenterol 2007, 21(Suppl C):25C-34C.

2. CHASE Project Team: Community Health and Safety Evaluation (CHASE) Project: Final Report 2005 [http://chase.hivnet.ubc.ca/project/pubdocs/ CHASE Reports/CHASE Final Report.pdf]. Downloaded April 13, 2010

3. Wood E, Kerr T, Stoltz J, Qui Z, Zhang R, Montaner JS, Tyndall MW: Prevalence and correlates of hepatitis $C$ infection among users of
North America's first medically supervised safer injection facility. Public Health 2005, 119:1111-1115.

4. Miller CL, Wood E, Spittal PM, Li K, Frankish JC, Braitstein P, Montaner JS, Schechter MT: The future face of coinfection: prevalence and incidence of HIV and hepatitis $C$ virus coinfection among young injection drug users. J Acquir Immune Defic Syndr 2004, 36:743-749.

5. Sulkowski MS, Thomas DL: Perspectives on HIV/hepatitis C virus coinfection, illicit drug use and mental illness. AIDS 2005, 19(Suppl 3):S8-12.

6. Pineda JA, Romero-Gomez M, Diaz-Garcia F, Giron-Gonzalez JA, Montero JL, Torre-Cisneros J, Andrade RJ, Gonzalez-Serrano M, Aguilar J, AguilarGuisado M, Navarro JM, Salmerón J, Caballero-Granado FJ, García-García JA: HIV coinfection shortens the survival of patients with hepatitis $C$ virus-related decompensated cirrhosis. Hepatology 2005, 41:779-789.

7. Antonucci G, Girardi E, Cozzi-Lepri A, Capobianchi MR, Morsica G, Pizzaferri P, Ladisa N, Sighinolfi L, Chiodera A, Solmone M, Lalle E, Ippolito G, Monforte A, HepalCoNA Study Group, ICoNA Study Group: Response to HAART and GB virus type $C$ coinfection in a cohort of antiretroviralnaive HIV-infected individuals. Antivir Ther 2005, 10:109-117.

8. Carter M: HCV coinfection hastens HIV disease progression. IAPACMon 2004, 10:433.

9. Hershow RC, O'Driscoll PT, Handelsman E, Pitt J, Hillyer G, Serchuck L, Lu M, Chen KT, Yawetz S, Pacheco S, Davenny K, Adeniyi-Jones S, Thomas DL: Hepatitis $C$ virus coinfection and HIV load, CD4+ cell percentage, and clinical progression to AIDS or death among HIV-infected women: Women and Infants Transmission Study. Clin Infect Dis 2005, 40:859-867.

10. Rodriguez B, Bobak DA: Management of Hepatitis C in HIV-infected Patients. Curr Infect Dis Rep 2005, 7:91-102.

11. Aranzabal L, Casado JL, Moya J, Quereda C, Diz S, Moreno A, Moreno L, Antela A, Perez-Elias MJ, Dronda F, Marín A, Hernandez-Ranz F, Moreno A, Moreno $S$ : Influence of liver fibrosis on highly active antiretroviral therapy-associated hepatotoxicity in patients with HIV and hepatitis $C$ virus coinfection. Clin Infect Dis 2005, 40:588-593.

12. Fuster D, Planas R, Muga R, Ballesteros AL, Santos J, Tor J, Sirera G, Guardiola H, Salas A, Cabre E, Ojanguren I, Barluenga E, Rey-Joly C, Clotet $B$, Tural C: Advanced liver fibrosis in HIV/HCV-coinfected patients on antiretroviral therapy. AIDS Res Hum Retroviruses 2004, 20:1293-1297.

13. Cote P, Baril JG, Hebert MN, Klein M, Lalonde R, Poliquin M, Rouleau D, Therrien R, Vezina S, Willems B, Dion H, Junod P, Lapointe N, Lévesque D, Pinault L, Tremblay C, Trottier B, Trottier S, Tsoukas C, Piché A: Management and treatment of hepatitis $C$ virus in patients with HIV and hepatitis $C$ virus coinfection: A practical guide for health care professionals. Can J Infect Dis Med Microbiol 2007, 18:293-303.

14. Lee W, Dieterich D: Challenges in the management of HIV and hepatitis C virus co-infection. Drugs 2004, 64:693-700.

15. Plosker GL, Keating GM: Peginterferon-alpha-2a (40 kD) plus ribavirin: a review of its use in hepatitis C Virus And HIV co-infection. Drugs 2004, 64:2823-2843

16. Soriano V, Garcia-Samaniego J, Rodriguez-Rosado R, Gonzalez J, Pedreira J: Hepatitis C and HIV infection: biological, clinical, and therapeutic implications. J Hepatol 1999, 31(Suppl 1):119-123.

17. Bonacini M, Puoti M: Hepatitis $C$ in patients with human immunodeficiency virus infection: diagnosis, natural history, metaanalysis of sexual and vertical transmission, and therapeutic issues. Arch Intern Med 2000, 160:3365-3373

18. Lesens O, Deschenes M, Steben M, Belanger G, Tsoukas CM: Hepatitis C virus is related to progressive liver disease in human immunodeficiency virus-positive hemophiliacs and should be treated as an opportunistic infection. J Infect Dis 1999, 179:1254-1258.

19. Benhamou Y, Bochet M, Di MV, Charlotte F, Azria F, Coutellier A, Vidaud M, Bricaire F, Opolon P, Katlama C, Poynard T: Liver fibrosis progression in human immunodeficiency virus and hepatitis $C$ virus coinfected patients. The Multivirc Group. Hepatology 1999, 30:1054-1058.

20. Cacoub P: Treatment of hepatitis C in HIV/hepatitis C co-infected patients: what is the evidence? Int J STD AIDS 2005, 16:1-4.

21. Romero M, Perez-Olmeda M, Garcia-Samaniego J, Soriano V: Management of chronic hepatitis $\mathrm{C}$ in patients co-infected with HIV: focus on safety considerations. Drug Saf 2004, 27:7-24.

22. Sulkowski MS, Thomas DL: Hepatitis C in the HIV-infected patient. Clin Liver Dis 2003, 7:179-194

23. Maheshwari A, Ray S, Thuluvath PJ: Acute hepatitis C. Lancet 2008, 372:321-32. 
24. Liang TJ, Rehermann B, Seeff $L B$, Hoofnagle JH: Pathogenesis, natural history, treatment, and prevention of hepatitis C. Ann Intern Med 2000, 132:296-305.

25. Cooper C: HAART and Liver: a discussion of hepatic disease in those living with HIV. Interview by Paul C Adams. Can J Gastroenterol 2008, 22:973-975.

26. Bodsworth NJ, Cunningham P, Kaldor J, Donovan B: Hepatitis C virus infection in a large cohort of homosexually active men: independent associations with HIV-1 infection and injecting drug use but not sexual behaviour. Genitourin Med 1996, 72:118-122.

27. Myers T, Allman D, Xu K, Remis RS, Aguinaldo J, Burchell A, Calzavara L, Swantee $C$ : The prevalence and correlates of hepatitis $C$ virus (HCV) infection and HCV-HIV co-infection in a community sample of gay and bisexual men. Int J Infect Dis 2009, 13:730-9.

28. Urbanus AT, Laar TJ van de, Stolte IG, Schinkel J, Heijman T, Coutinho RA, Prins M: Hepatitis $C$ virus infections among HIV-infected men who have sex with men: an expanding epidemic. AIDS 2009, 23:F1-F7.

29. Pelgrom JM, Vogelaers D, Colle I: Hepatitis C-seroconversion within three to six months after having contracted clinical syphilis and/or lymphogranuloma venereum rectitis in five homosexually active, HIV seropositive men. Acta Clin Belg 2008, 63:335-338.

30. Gotz HM, van Doornum G, Niesters HG, den Hollander JG, Thio HB, de Zwart O: A cluster of acute hepatitis $\mathrm{C}$ virus infection among men who have sex with men--results from contact tracing and public health implications. AIDS 2005, 19:969-974.

31. Van Den BC, Smit C, Van Brussel G, Coutinho R, Prins M: Full participation in harm reduction programmes is associated with decreased risk for human immunodeficiency virus and hepatitis $C$ virus: evidence from the Amsterdam Cohort Studies among drug users. Addiction 2007, 102:1454-1462

Pre-publication history

The pre-publication history for this paper can be accessed here: http://www.biomedcentral.com/1471-2458/10/225/prepub

doi: $10.1186 / 1471-2458-10-225$

Cite this article as: Buxton et al., HCV co-infection in HIV positive population in British Columbia, Canada BMC Public Health 2010, 10:225

\section{Submit your next manuscript to BioMed Central} and take full advantage of:

- Convenient online submission

- Thorough peer review

- No space constraints or color figure charges

- Immediate publication on acceptance

- Inclusion in PubMed, CAS, Scopus and Google Scholar

- Research which is freely available for redistribution

Submit your manuscript at www.biomedcentral.com/submit
C Biomed Central 